\title{
Synthesis, Solution Stability, and Crystal Structure of Aza-thia Macrocyclic Complexes of Silver(1)
}

\author{
Andrew S. Craig, ${ }^{a}$ Ritu Kataky, ${ }^{a}$ David Parker, ${ }^{* a}$ Harry Adams, ${ }^{b}$ Neil Bailey, ${ }^{b}$ and Herrmann Schneiderc \\ a Department of Chemistry, University of Durham, South Road, Durham DH1 3LE, U.K. \\ b Department of Chemistry, University of Sheffield, Sheffield S3 7HF, U.K. \\ c Max-Planck Institut für Biophysikalische Chemie, D-3400 Göttingen, F.R.G.
}

The synthesis of the [18]- $\mathrm{N}_{4} \mathrm{~S}_{2}$ coronand is reported with the crystal structure of the silver complex and determinations of complex stability in both methanol and water.

During the course of studies directed towards the synthesis of kinetically inert silver(I) complexes, a series of mixed donor [18]-ring coronands have been compared. A motivation for this work was the desire to find a ligand which bound silver(I) sufficiently quickly $(\leqslant 2 \mathrm{~h})$ in aqueous media $(\mathrm{pH} 4-7$, $298-310 \mathrm{~K}$ ) to yield a complex that was stable with respect to silver loss in vivo permitting its use in ${ }^{111} \mathrm{Ag}$-based radioimmunotherapy $\left(t_{1 / 2}=179 \mathrm{~h}\right.$, mean range in tissue $=1.1 \mathrm{~mm}$, max energy $=1.04 \mathrm{MeV})$. Although considerable progress has been made with other metallic therapeutic radioisotopes, notably ${ }^{67} \mathrm{Cu}$ (ref. 1) and ${ }^{90} \mathrm{Y}^{2}$ there are no reports of complexes of silver(I) which possess sufficient stability with respect to acid, or metal-catalysed dissociation to permit their use in vivo. Earlier studies have defined the binding abilities of [18] $-\mathrm{N}_{2} \mathrm{~S}_{4},{ }^{3} \mathrm{~N}_{2} \mathrm{O}_{4},{ }^{4} \mathrm{~S}_{2} \mathrm{O}_{4},{ }^{5}$ and $\mathrm{N}_{4} \mathrm{O}_{2}{ }^{6}$ for certain transition metal ions including silver(I) (except for $\mathrm{N}_{4} \mathrm{O}_{2}$ ). Given the enthalpic donor atom preference of silver for $\mathrm{S}>\mathrm{NH}>\mathrm{O}$, and bearing in mind the unfavourable entropy of complexation introduced by incorporation of a sulphur atom into macrocyclic ligands, ${ }^{7}$ the $[18]-\mathrm{N}_{4} \mathrm{~S}_{2}$ system has been examined.
Reaction of ethylenediamine with thiodiglycollic anhydride in $\mathrm{CH}_{2} \mathrm{Cl}_{2}$ followed by esterification $(\mathrm{EtOH} / \mathrm{HCl})$ yielded the diamide (2) (m.p. 93-94 ${ }^{\circ} \mathrm{C}, 27 \%$ ). Condensation with ammonia in ethanol gave the tetra-amide (3) (m.p. 186-

Table 1. Thermodynamic parameters for silver complexes of [18]monocycles $(298 \mathrm{~K}, \mathrm{MeOH})$.

$\begin{array}{lccc}\text { Ligand } & \begin{array}{c}\log K_{\mathrm{S}} \\ / \mathrm{mol}^{-1} \mathrm{dm}^{3}\end{array} & -\Delta \mathrm{H} / \mathrm{kJ} \mathrm{mol}^{-1} & T \Delta S / \mathrm{kJ} \mathrm{mol}^{-1} \\ \text { a) } \mathrm{N}_{4} \mathrm{~S}_{2} & 14.1 & 77.0 & +3.3 \\ \text { b) } \mathrm{N}_{4} \mathrm{~S}_{2} \mathrm{Me}_{4} & 14.6 & 102.1 & -18.7 \\ \text { a) } \mathrm{N}_{4} \mathrm{O}_{2} & 11.2 & - & - \\ \mathrm{N}_{4} \mathrm{O}_{2} \mathrm{Me}_{4} & 13.4 & 84.3 & -7.8 \\ \text { a) } \mathrm{N}_{2} \mathrm{O}_{4}{ }^{a} & 10.0 & 51.4 & +5.7 \\ \text { b) } \mathrm{S}_{2} \mathrm{O}_{4}{ }^{\mathrm{a}} & 10.3 & 64.0 & -5.3 \\ \text { c) } \mathrm{O}_{6}{ }^{\mathrm{b}} & 4.6 & 38.3 & -12.1 \\ \mathrm{~N}_{2} \mathrm{~S}_{4}{ }^{\mathrm{a}} & 13.7 & 83.2 & -5.0\end{array}$

a Data from ref. 11. b Data from ref. 12. ${ }^{\mathrm{c}}$ Errors on $\log K$ are typically $( \pm 0.1)$ or less, and for $\Delta H \pm 0.3 \mathrm{~kJ} \mathrm{~mol}^{-1}$, or less. 
J. CHEM. SOC., CHEM. COMMUN., I 989

Table 2. Protonation constants for the ligands and binding constants for silver complexes of $(\mathbf{1})^{\mathrm{a}}\left(298 \mathrm{~K}, \mathrm{H}_{2} \mathrm{O}, I=0.1 \mathrm{NMe}_{4} \mathrm{NO}_{3}\right)$.

$\begin{array}{ccccccccc}\text { Ligand } & \mathrm{p} K_{1} & \mathrm{p} K_{2} & \mathrm{p} K_{3} & \mathrm{p} K_{4} & \log K_{\mathrm{AgL}} & \log K_{\mathrm{AgLH}} & \log K_{\mathrm{AgLH} 2} & \log K_{\mathrm{AgLH} 3} \\ \text { (1a) } & 9.26 & 8.45 & 5.81 & 4.88 & 10.4 & 9.05 & 6.00 & 4.13 \\ & & & & & (7.91) & (5.40) & (3.94) & \\ \text { (1b) } & 8.82 & 8.35 & 4.13 & 3.71 & 9.47 & 8.06 & 4.31 & \end{array}$

a Values in parentheses refer to protonation constants of the complexes $( \pm 0.10)$. ${ }^{\mathrm{b}} \mathrm{pH}$-metric data were analysed by SCOGS-2 and SUPERQUAD.

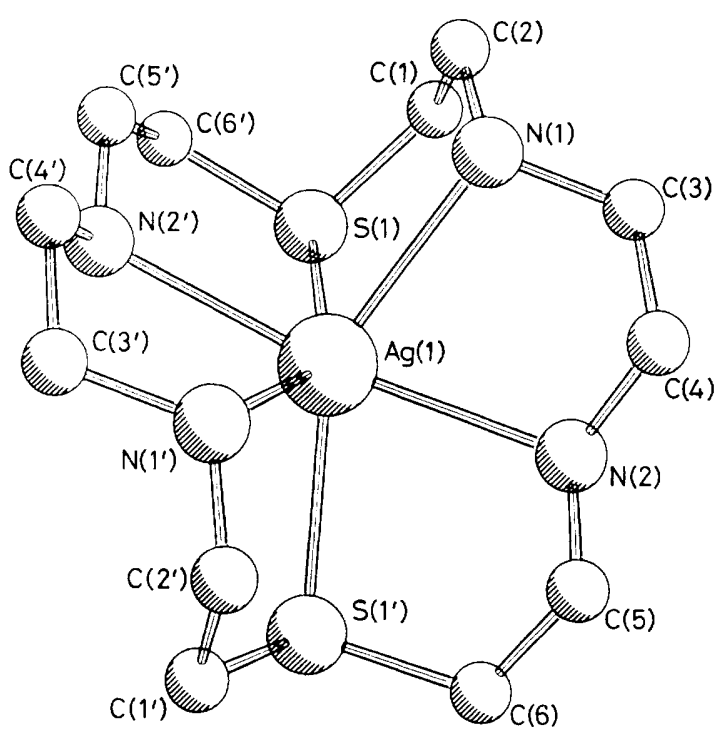

Figure 1. Structure of $[(1 \mathrm{a}) \cdot \mathrm{Ag}]^{+}$in the crystal. Selected bond lengths $(\AA)$ and bond angles $\left({ }^{\circ}\right): \mathrm{Ag}-\mathrm{S}(1)=2.658(5), \mathrm{Ag}-\mathrm{N}(1)=2.589(10)$, $\mathrm{Ag}-\mathrm{N}(2)=2.553(11) ; \mathrm{S}(1)-\mathrm{Ag}-\mathrm{N}(1) 75.9(3), \mathrm{S}(1)-\mathrm{Ag}-\mathrm{N}(2) 113.2$, $\mathrm{S}(1)-\mathrm{Ag}-\mathrm{S}\left(1^{\prime}\right) \quad 124.5(2), \mathrm{N}(1)-\mathrm{Ag}-\mathrm{N}\left(1^{\prime}\right)$ 104.3(4), N(2)-Ag-N $\left(2^{\prime}\right)$ $164.3(5)$

$187^{\circ} \mathrm{C}, 76 \%$ ) and reduction with $\mathrm{BH}_{3} \cdot \mathrm{THF}$ (THF = tetrahydrofuran) afforded the tetra-amine $(4)$ as a colourless oil $(71 \%)$. Tosylation $\left[\mathrm{TsCl} / \mathrm{py}\left(\mathrm{Ts}=\mathrm{OSO}_{2} \mathrm{C}_{6} \mathrm{H}_{4} \mathrm{Me}-p\right)\right]$ yielded the tetra-tosylamide (5) (m.p. $131-133^{\circ} \mathrm{C}, 56 \%$ ) and cocyclisation with 1,2-bis(toluene-p-sulphonato)ethane in dimethylformamide (DMF) in the presence of $\mathrm{Cs}_{2} \mathrm{CO}_{3}$ gave the cycle (1c) (m.p. $254-6{ }^{\circ} \mathrm{C}, 62 \%$ ). Detosylation under reductive conditions $\left(\mathrm{Li} / \mathrm{NH}_{3} / \mathrm{THF}-\mathrm{MeOH}\right)$ permitted the isolation of the tetra-amine (1a) (m.p. 88-9 ${ }^{\circ} \mathrm{C}, 64 \%$ ) and Eschweiler-Clarke methylation gave the corresponding tertiary amine (1b) (m.p. $43-44^{\circ} \mathrm{C}, 56 \%$ ).

Admixture of (1a) and silver nitrate $(1: 1$ in $\mathrm{MeOH})$ followed by addition of $\mathrm{NH}_{4} \mathrm{PF}_{6}$ led to isolation of the colourless crystalline complex (following slow solvent evaporation). The crystal structuret revealed that the complex possessed crystallographically imposed $C_{2}$ symmetry with the silver cation lying on the symmetry axis. The silver ion is hexaco-ordinated by the $\mathrm{N}_{4} \mathrm{~S}_{2}$ donor atoms in a distorted octahedral geometry (Figure 1). The pair of ligands which are

+ Crystal data for $\left[\mathrm{C}_{12} \mathrm{H}_{28} \mathrm{~N}_{4} \mathrm{~S}_{2} \mathrm{Ag}\right]+\mathrm{PF}_{6}{ }^{-}$: orthorhombic, Pbcn, $a=$ $10.859(22), b=20.247(26), c=9.742(10) \AA, U=2142(6) \AA^{3}, D_{\mathrm{c}}=$ $1.691 \mathrm{~g} \mathrm{~cm}^{-3}, Z=4, F(000)=1103.8, \mu\left(\mathrm{Mo}-K_{\alpha}\right)=12.46 \mathrm{~cm}^{-1}$. Refinement converged at $R=0.072$, with evidence of some disorder in the $\mathrm{PF}_{6}$ counterion. Atomic co-ordinates, bond lengths and angles, and thermal parameters have been deposited at the Cambridge Crystallographic Data Centre. See Notice to Authors, Issue No. 1.

(a)

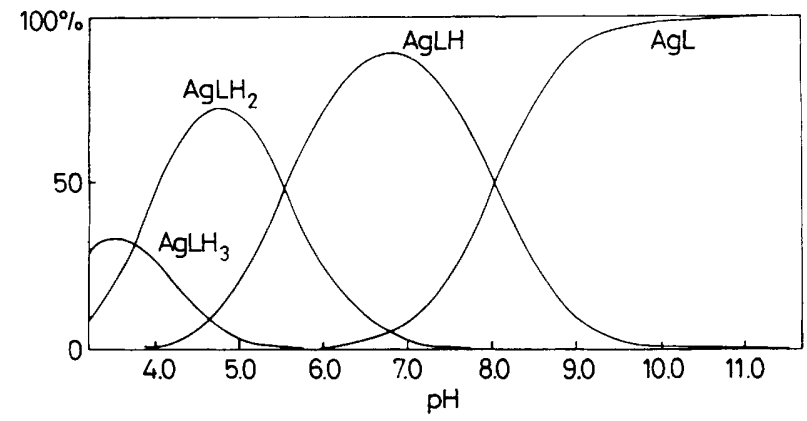

(b)

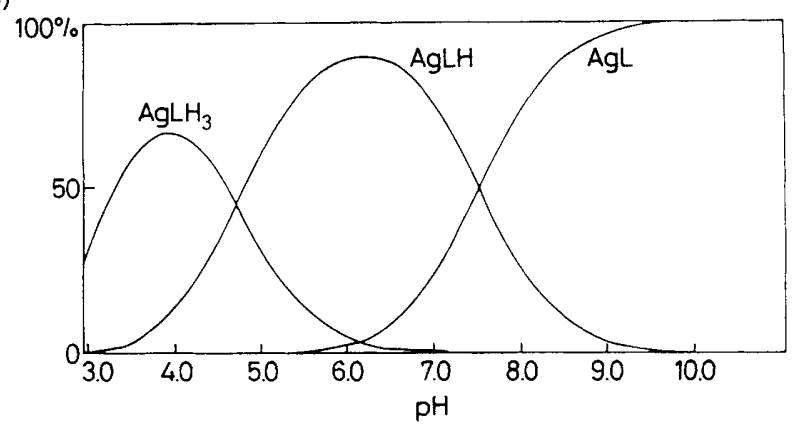

Figure 2. Species distribution plots for (a) $\left\lfloor(\mathbf{1 a}) \cdot \mathrm{AgH}_{n}\right\rfloor$ and (b) $\left[(\mathbf{1 b}) \cdot \mathrm{AgH}_{n}\right]$ (lower).

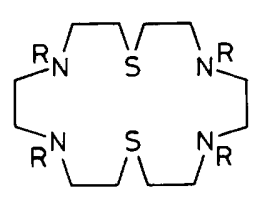<smiles>O=C(O)CSCC(=O)NCCNC(=O)CSCC(=O)O</smiles>

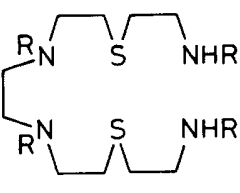
(1) $a ; R=H$
b; $\mathrm{R}=\mathrm{Me}$
c; $R=T s$

(2) $x=O E t$

(4) $\mathrm{R}=\mathrm{H}$

(3) $X=\mathrm{NH}_{2}$

(5) $R=T s$
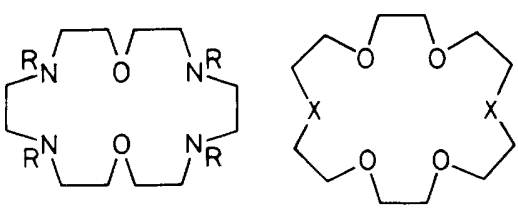

(6) $a ; R=H$

b; $R=M e$

c; $R=T s$
(7) $\mathbf{a} ; \mathrm{X}=\mathrm{NH}$

b; $X=5$

c: $X=0$

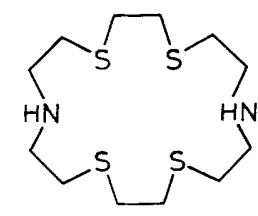

(8) 
most nearly trans-disposed are the $C_{2}$-related nitrogen atoms $N(2)$ and $N\left(2^{\prime}\right)$ at $164.3(5)^{\circ}$. Considering these atoms as the axial sites, $\mathrm{S}(1)$ and $\mathrm{N}\left(1^{\prime}\right)$ are displaced below the equatorial plane by 0.68 and $0.82 \AA$ respectively with their $C_{2}$-related counterparts displaced equally above this plane. Surprisingly, none of the secondary amines participate in any hydrogen bonding to either cation or anion: the shortest contact is from $\mathrm{N}(1)-\mathrm{H}(1)$ to $\mathrm{F}(3)$ of a symmetry related $\mathrm{PF}_{6}$ anion $[\mathrm{N}(1) \cdots \mathrm{F}(3)=3.32 ; \mathrm{H}(1) \cdots \mathrm{F}(3)=2.40 \AA]$. There are very few reports of structural determinations of silver complexes of [18]-ring coronands. A dimeric complex with the pyridine- $\mathrm{NS}_{2} \mathrm{O}_{3}$ cycle has been reported 8 and the silver complex of [18]-S 6 has been defined, ${ }^{9}$ with two short $(2.666 \AA)$ and four longer $(2.781 \AA$ ) silver-sulphur bonds.

The enthalpy of complexation of (1a), (1b), (6a), and (6b) $\ddagger$ was measured by calorimetric methods in anhydrous $\mathrm{MeOH}$, and stability constants were determined potentiometrically, ${ }^{10}$ thereby permitting calculation of the entropy of complexation. Values are given in Table 1 and a comparison has been made with values measured, by similar methods, in previous work with other [18]-ring mixed donor coronands. ${ }^{11}$ Certain trends are apparent; sulphur donors in the ring give rise to favourable enthalpies of complexation but this is offset by the unfavourable entropy change [via (1a) vs. (6a); (7a) vs. (7b); (7a) vs. (8); (1b) vs. (6b)]. This phenomenon is associated with the propensity of sulphur lone pairs in the free ligand to adopt exodentate conformations ${ }^{7}$ in the free ligand and hence an unfavourable conformational re-ordering is necessary prior to metal ion complexation. $N$-Methylation leads to enhanced enthalpies of complexation [NMe vs. NH: (1a) vs. (1b)] but markedly unfavourable entropies of complexation. Evidently for $[(\mathbf{1 b}) \cdot \mathrm{Ag}]^{+}$in order to minimise non-bonding $\mathrm{N}-\mathrm{Me} /-$ $\mathrm{N}-\mathrm{Me}$ interactions, the ring has deformed into a markedly different conformation from that of the free ligand.

The protonation and silver complexation equilibria for (1a) and (1b) have also been studied in aqueous solution (198 K, I $=0.1 \mathrm{NMe}_{4} \mathrm{NO}_{3}$ ) using pH-metric methods (Table 2). The protonated silver complexes have good stabilities compared to the parent complex, because loss of one nitrogen binding site does not greatly impair silver complexation. Such a situation

$\ddagger$ The coronand (6a) was prepared by co-cyclisation of ethylenediamine ditosylamide with 3-oxa-1,5-bis(toluene- $p$-sulphanato)pentane (DMF, $\left.\mathrm{Cs}_{2} \mathrm{CO}_{3}\right),(20 \%)$, followed by detosylation $(\mathrm{HBr}, \mathrm{AcOH}$, $\mathrm{PhOH})$. may be contrasted with the more dramatic loss of binding that occurs on protonation of silver complexes of poly-aza cryptands. ${ }^{13}$ Species distribution plots as a function of $\mathrm{pH}$ are given (Figure 2): it is evident that at $\mathrm{pH}<5$, dissociation of silver will occur indicating that these silver complexes will not be sufficiently stable in vivo for any practical use. It remains a considerable challenge to devise a silver-ligand system that possesses sufficient stability at low $\mathrm{pH}$ to minimise decomplexation, yet may be formed quickly $(\leqslant 2$ h) under ambient physiological conditions.

We thank the S.E.R.C. and Celltech Ltd. for a CASE studentship (A. S. C.) and D. P. thanks the Royal Society of Chemistry for a Hickinbottom Fellowship.

Received, 21st August 1989; Com. 9/04038B

\section{References}

1 J. R. Morphy, R. Kataky, D. Parker, M. A. W. Eaton, A. T. Millican, A. Harrison, and C. Walker, J. Chem. Soc., Chem. Commun., 1989, 792.

2 J. P. L. Cox, K. J. Jankowski, D. Parker, R. Kataky, M. A. W. Eaton, N. R. A. Beeley, A. T. Millican, K. Millar, B. A. Boyce, A. Harrison, and C. Walker, J. Chem. Soc., Chem. Commun., 1989, 796.

3 D. St. C. Black and I. A. McLean, J. Chem. Soc., Chem. Commun., 1968, 1004; A. Alberts, J. M. Lehn, and D. Parker, J. Chem. Soc., Dalton Trans., 1985, 2311; T. Burchard, Ph.D. Thesis, University of Dortmund, 1984.

4 J. M. Lehn and J. P. Sauvage, J. Am. Chem. Soc., 1975, 97, 6700; H. J. Buschmann, Inorg. Chim. Acta, 1985, 102, 95.

5 H. J. Buschmann, Chem. Ber., 1985, 118, 4297.

6 E. Luboch, A. Cygan, and J. F. Biernat, Inorg. Chim. Acta, 1983, $168,201$.

7 R. E. Wolf, J. R. Hartman, J. M. E. Storey, B. M. Foxman, and S. R. Cooper, J. Am. Chem. Soc., 1987, 109, 4328.

8 A. S. Craig, D. Parker, and G. Ferguson, Acta Crystallogr., Sect. C, 1989, 45(5), 741 .

9 A. J. Blake, R. O. Gould, A. J. Holder, T. I. Hyde, and M. Schroder, Polyhedron, 1989, 8(14), 513.

10 B. G. Cox, C. Guminski, and H. Schneider, J. Am. Chem. Soc., 1982, 104, 3789; B. G. Cox, P. Firman, H. Horst, and H. Schneider, Polyhedron, 1983 2, 343.

11 H. J. Buschmann, in 'Stereochemical and Stereophysical Behaviour of Macrocycles,' ed. I. Bernal, Elsevier, 1987, ch. 2.

12 J. D. Lamb, R. M. Izatt, S. W. Swain, and J. J. Christensen, J. Am. Chem. Soc., 1980, 102, 475.

13 J. M. Lehn and F. Montavon, Helv. Chim. Acta, 1978, 61, 67; only monoprotonated silver cryptates were observed. 